\title{
Pengembangan Kualitas SDM untuk Mendukung Pertumbuhan Ekonomi Indonesia dalam PJPT II
}

\author{
Oleh : Musllch.
}

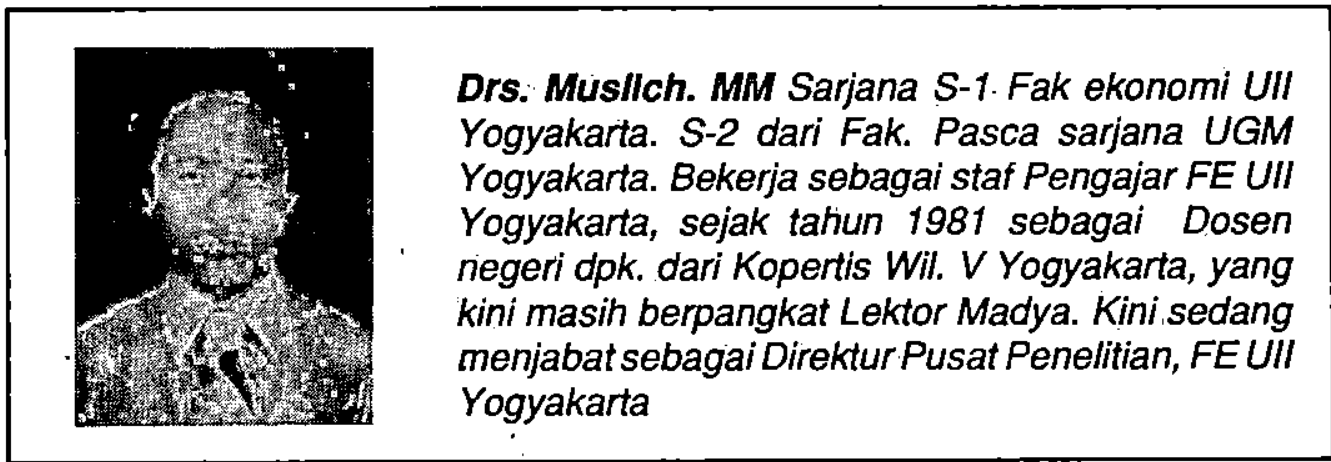

Menurut banyak para ahli dan pakar ekonomi dan pembangunan, disebutkan bahwa terdapat tiga macam resources yang selalu dibutuhkan di dalam memajukan pertumbuhan bisnis di negara manapun. Ketiga resources tersebut adalah : Human Resources yaitu sumber daya manusia, Financial resources yaitu sumber dana dan Information resources yaitu berbagai informasi yang dibutuhkan. Dari ketiga resources tersebut para ahli sependapat bahwa yang paling menentukan dan kunci adalah human resources, atau Sumber Daya Manusia. Sebagai contoh bagaimananegara Jepang dan Amerika dan umumnya di negara-negara maju yang telah terbukti bahwa kemajuan mereka amat ditentukan oleh pentingnya faktor manusia ini.

Berkaitan dengan itu bagi bangsa dan negara Indonesia yang akan memasuki PJPT II mendatang nampaknyanuansa pendalaman kiprah pembangunan Indonesia akanmakin menukik pada sektor-sektor yang makin strategis.

Strategis jika dilihat dari harapan kemampuannya untuk menggerakkan pembangunan ke arah yang lebih menitik beratkan pada sektor dan sub sektor pengembangan sumber daya manusia.

Harapan ini memang cukup beralasan dan memiliki bobot pembenaran yang cukup diterima di akal, karena yang dibangun adalah manusia Indonesia yang harus menguasai ilmu pengetahuan dan teknologi yang dibutuhkan untuk mendukung pengembangan manusia Indonesia.

Selain itu karena sudah tiba saatnya untuk memilih fokus sumber daya manusia yang kita yakini sebagai kunci keberhasilan pada periode PJPT II nanti, maka orientasi ini dalam memasuki PJPT II mendatang bukan berarti mengganti haluan, tapi ia merupakan proses kelanjutan saja dari PJPT I yang kini telah berakhir.

Kita mengetahui bahwa pada masa 25 tahun yang lalu pembangunan ekonomi 
yang kita lakukan untuk persiapan tinggal landas ini lebih difokuskan pada penyiapan sarana dan prasarana fisik dan perombakan struktur ekonomi. Selain itu pola kebijakan yang sering dipakai adalah pendekatan moneter, yang kurang menyentuh pada sektor-sektor riel. Selain itu upaya pengembangan sumber daya manusia, ilmu pengetahuan dan teknologi kurang dirasakan sebagai sektor yang diprioritaskan. Dengan pertimbangan itulah makauntuk kelanjutannya dalam memasuki saat tinggal landas pada PJPT II ini penekanan pada pengembangan kualitas sumberdaya manusia menjadi sesuatu yang sangat urgen dan perlu mendapat prioritas utama.

Dengan perkataan lain peran kemajuan ekonomi yang selama 25 tahun yang lalu sama-sama kita akui keberhasilannya itu harus dapat kita jadikan landasan pijak untuk menunjang upaya pengembangan sumber daya manusia dengan penguasaan ilmu pengetahuan dan teknologi yang cukup tinggi.

Berkaitandengan itu, pengembangan ekonomi di negeri kita ini tidak terlepas dengan peran yang dimainkan oleh SDM nya. Sebab faktorSDM dalam hal ini benarbenar telah diakui sebagai faktor yang strategis bagi kemajuan ekonomi dan kegiatan bisnis.

Oleh karena itu dalam tulisan ini dicoba dibahas peran yang diberikan kualitas sumber daya manusia terhadap intensitas kegiatan ekonomi dan bisnis, terutama bagi usaha meningkatkan keunggulan komparatif ekonomi Indonesia di forum global dan internasional. Dan sektor ekonomi mana saja sumber daya manusianya yang dapat dipacu pengembangannya.

\section{Pentingnya Pengembangan Kualitas SDM.}

Di dalam literatur ekonomi disebutkan bahwa di antara faktor-faktor produksi (yang secara lebihluas disebutkan sebagai Sumber Daya Ekonomi) itu, maka yang menjadi peran kuncinya adalah terletak pada faktor/sumber daya "manusianya". Betapapun cukup tersedia secara berlimpah sumber daya ekonomi selain SDM yang kita kuasai, itupun tidak banyak memberikan arti bagi pengembangan ekonomi dan nilai tambah yang tinggi kalau tanpa pengembangan kualitas sumber daya manusia yang mengelolanya.

Sebagai salah satu faktor produksi yang khas, SDM merupakan kunci strategis yangpaling menentukan bagi keberhasilan kegiatan bisnis dan pertumbuhan ekonomi. Justru dengan pertimbangan itulah maka usaha untuk mengembangkan mutu SDM perlumenjadi fokusutama dalam memasuki PJPT II mendatang ini.

Kualitas SDM dapat dikategorikan sebagai memiliki kualifikasi tinggi manakala warga negara yang menjadi pelaku bisnis dan ekonomi memiliki Kemampuan, Ketrampilan dan Keahlian, dalam bidangnya masing-masing.

Kalau seseorang disebut mampu melaksanakan sesuatu pekerjaan secara baik, tentu orang tersebut memiliki kesiapan dan bekal yang cukup, baik secara fisik maupun non fisik, untuk menyelesaikan pekerjaannya. Kalau sudah dikatakan memiliki bekal(kesiapan) yang cukupuntuk menyelesaikan pekerjaan, tentu dalam realisasinya orang tersebut cukup terampil.

Tetapi dalam menyelesaikan pekerjaan tersebut, tentu hasil yang dicapai 
memiliki kadar kualifikasi tertentu. Untuk itu kalau seseorang telah mencapai suatu hasil pekerjaan yang memiliki kualifikasi tertentu yang cukup tinggi, maka orang tersebut dapat kita sebut sebagai telah memiliki keahlian yang cukup handal. Ini suatu kreteria yang secara umum harus dibekali dengan penguasaan ilmu pengetahuan dan penguasaan teknologi. Pembekalan yang mesti dilakukan melalui pendidikan dan latihan, baik secara formal maupun non formal, baik oleh pemerintah maupun oleh masyarakat sendiri. Pembekalan ini harus menjadi prioritas secara terus menerus dalam waktu yang lama.

Tingkat penguasaan atas ilmu pengetahuan dan teknologi bagi setiap individu akan sangat mendukung terhadap performance nya. Tingkat pengaruhnya jelas sangat besar terhadap peningkatan kinerja. Produk yang dihasilkan adalah produk yang makin tinggi kualitasnya. Dan makin handal bagi usaha memenangkan dalam kompetisi di pasar global dan internasional, yang pada akhimya makin besar pengaruhnya terhadap usaha meningkatkan ekonomi masyarakat secara lebih luas.

\section{Beberapa Profesi dan Sektor Ekonomi Prioritas.}

Sebagaimana kita ketahui bahwa langkah-langkah yang telah dan terus akan dilakukan dalam mengantisipasi serta menyongsong era globalisasi ekonomi adalah: 1. mengembangkan industri dengan daya saing yang kuat, 2. meningkatkan daya saing produk industri dan 3 . secara offensif terus menggalakkan ekspor non migas.
Sudah tentu untuk mendukung keberhasilan langkah yang telah dicanangkan tersebut aspek yang sangat menonjol yang harus dilakukan adalah usaha pengembangan SDM nya.

SDM yang ingin kita tingkatkan kualifikasinya ini adalah sumber daya manusia yang secara langsung terkait dengan upaya peningkatan kualifikasi produk industri dalam menghadapi arus globalisasi tersebut, baik pada pasar domestikmaupun pada pasarekspor. Untuk itu kita memerlukan suatu kajian yang cukup bertanggung jawab agar supaya pengembangan SDM tersebut benar-benar sesuai dengan target danlangkah yang sudah digariskan di atas.

\section{Tabel 1}

Prosentase penduduk yang bekerja menurut jenis pekerjaan ( dalam \% ).

Jenis Pekerjaan . . $\quad 1971 \quad 19801990$

$\begin{array}{lrrr}\text { 1. Profesional dan Teknisi } & 2,2 & 2,9 & 3,7 \\ \text { 2. Kepemimp. \& Tata laksana } & 0,5 & 0,1 & 0,2 \\ \text { 3. Tata Usaha } & 3,2 & 3,5 & 4,9 \\ \text { 4. Penjualan } & 10,6 & 12,9 & 14,3 \\ \text { 5. Jasa-jasa } & 3,9 & 4,3 & 4,2 \\ \text { 6. Petani } & 63,9 & 55,8 & 49,9 \\ \text { 7. Produksi dan Alat Angkut } & 11,8 & 19,0 & 22,1 \\ \text { 8. Lain-lain } & 3,9 & 0,7 & 0,1 \\ & & & \end{array}$

Sumber : Biro Pusat Statistik, Jakarta 1992.

Dilihat dari profesi pekerjaan yang dilakukan oleh SDM Indonesia dalam rangka untuk mendukung peningkatan nilai tambah ekonomi secara luas, maka kita dapat mengharapkan agar SDM yang perlu mendapat perhatian untuk lebih cepat berkembang atau meningkat kualifikasinya 
adalah pada jenis Profesional dan Teknisi, termasuk - wiraswastawan, yaitu orang: orang yang mampu menciptakan gagasan atau ide usaha-usaha baru.

Kalaupun tingkat perkembangannya dari tahun 1971 sampai dengan tahun 1990 secara prosentatif relatif rendah namun jumlah ini diharapkan akan makin meningkat di masa-masa mendatang dengan memberikan kesempatan dan kemudahan yang lebih merata dan adil atas iklim usaha kepada siapa saja. Pemberian pelayanan dan pengalaman untuk berkembang dalam usaha meningkatkan karir profesinya, tanpa harus dibedakan pro atau kontranya dengan pemerintah, misalnya. Semua peluang dan pengálaman harus diberikan kepada semua warga negara yang memiliki potensi yang. layak, yang berbakat meningkatkan ketrampilan dan keahliannyasehingga dapat mèndukung bagi kemajuanekonomi rakyat banyak. Bobot penekanan selanjutnya adalah pada profesi Tata Laksana dan Kepemimpinan, profesi Tata Usaha, Penjualan, Jasa-jasa dan Petani. Profesi mereka ini meski juga dikembangkan dengan perlakuan yang sama dengan profesi sebelumnya. Hal ini dengan alasan karena profesi-profesi ini dalam proses percepatan peningkatan nilai tambah akan sangat kuat dukungannya terhadap upaya peningkatan ekonomi nasional.

Demikian juga atas profesi produksi yang operasi alat-alat angkut juga merupakan profesi yang tidak kalahpenting. Karena profesi Produksi dan Operasi alatalat angkut juga merupakan kunci keberhasilan dalam memenangkan persaingan di masa atau era globalisasi ekonomi. Kualifikasi produk yang diproses dalam produksi akan sangat ditentukan oleh ketrampilan dan penguasaan yang lebih tịnggi serta keahlian yang makin handal dalam mendesign dan memodifikasi produk tersebut sesuai dengan selera pasamya.

\section{Tabel 2}

Prosentase Penduduk yang bekerja Menurut Lapangan Usaha (dalam \% )

\begin{tabular}{lrrr}
\hline Lapangan Usaha . & 1971 & 1980 & 1990 \\
\hline Pertanian . & 66,3 & 55,9 & 49,9 \\
Pertambangan \& Penggalian & 0,2 & 0,8 & 1,0 \\
Industri Pengolahan & 6,8 & 9,1 & 11,4 \\
Listrik, Gas, Air minum & 0,1 & 0,1 & 0,2 \\
Bangunan & 1,7 & 3,2 & 4,1 \\
Perdagangan & 10,8 & 13,0 & 14,7 \\
Angkutan \& Komunikasi & 2,4 & 2,8 & 3,7 \\
Keuangan & 0,2 & 0,6 & 0,9 \\
Jasa-jasa & 10,4 & 13,9 & 13,0 \\
Lain-lain & 1,1 & 0,6 & $-0,9$ \\
T T. & 0,0 & 0,6 & 0,9 \\
\hline
\end{tabular}

Sumber BPS tahun 1992

TT $=$ tidak terjawab.

Bagaimanapun juga jika dilihat dari sektor-sektor ekonomi yang mampu menyerap banyak sumber daya manusia nampak masih didominasi oleh sektor pertanian. Disusul kemudian sektor perdagangan, Jasa-Jasa dan sektor.Industri pengolahan.

Sektor pertanian yang secara dominan cukup besar menampung SDM, maka permasalahannya akan makin. strategis jika kita tingkatkan peran dan kualifikasinya tenaga kerja yang bekerja pada sektor ini.

Secara historis memang struktur penduduk kita adälah dominan pada agraris. Oleh karena itu cukup bẹalasan jika tenaga kerja yang bekerja pada sektor ini terutama pada 
strata petani yang memang potensial berminat untukmaju, perlu kita perkenalkan dan kembangkan teknologi-teknologi baru yang berkaitann dengan budi daya hasilhasil pertanian agar supaya di masa PJPT II kelak segmen petani ini benar-benar tetap memberikan porsi pendukung kemajuan sektor industri yang makin kuat. Karena itu penyuluhan harus lebih intensif dan kerahkan dalam skala yang makin luas.

Di lain pihak jika kita ingin memberikan kesempatan yang makin luas pada sektorsektor Industri yang kita yakini sebagai kunci bagi kemajuan perekonomian kita dalam memasuki PJPT II mendatang, maka porsi pengembangan kualitas SDM pada sektor ini perlu lebih ditingkatkan lagi. Hal ini sebagaimana dapat kita lihat prospektifnya dalam tabel berikut ini.

\section{Tabel 3}

Peran Ekspor Hasil Industri Terhadap ekspor non migas.

Dan terhadap ekspor total (dalam \%)

$\begin{array}{llllllll}85 & 86 & 87 & 88 & 89 & 90 & 91 & 92 *\end{array}$

Thd.non migas $70,1 \quad 78,4 \quad 81,4 \quad 81,4 \quad 82,1 \quad 82,8 \quad 84,2 \quad 85,1$ $\begin{array}{llllllll}\text { Thd total } \quad 23,3 & 30,9 & 39,3 & 348,8 & 49,9 & 47,1 & 52,9 & 57,4\end{array}$

Sumber : Biro Pusat Statistik, Jakarta 1992.

Keterangan : * antara Januari-Agustus 1992 -

Cukup besar peran yang diemban sektor industri terhadap nilai ekspor non migas sepanjang tahun analisa ini. Pertumbuhannya menunjukkan suatu tingkat antara $70 \%$ $\mathrm{s} / \mathrm{d} 90 \%$. Sementara dari total nilai ekspor telah melampoui angka 50\% pada tahuntahun terakhir ini. Ini menunjukkan dominasi peran yangmakin besardan makin strategis jika kita proyeksikan terhadap penyerapan sumber daya manusia.

\section{Tabel 4}

Penyerapan Tenaga Kerja Sektor Industri (dalam ribuan)

\begin{tabular}{lrrrrrrr}
$\begin{array}{l}\text { Kelompok } \\
\text { Industri }\end{array}$ & 85 & 86 & 87 & 88 & 89 & 90 & 91 \\
\hline Aneka Ind. & 57,5 & 177,5 & 308,4 & 539,5 & 841,7 & 1381,5 & 1804,4 \\
IK D & 8,0 & 9,1 & 17,1 & 22,9 & 38,5 & 51,5 & 36,2 \\
IMLDE & 20,3 & 17,7 & 18,2 & 44,1 & 67,2 & 99,1 & 149,9 \\
Ind. Kecil & 556,9 & 174,3 & 179,6 & 363,3 & 601,0 & 841,9 & 1027,8
\end{tabular}

Sumber : Unisia, no. 15 th. XIII-IV-1992, hal 53 diolah kembali.

Keterangan :

IKD Industri Kimia Dasar

IMLDE Industri Mesin Logam Dasar dan Elektronik

Jika kita perhatikan pada masing-masing sub sektor industri ini, maka sejak $85 \mathrm{~s} / \mathrm{d} 89$ peranan sektor Aneka Industri masih cukup besardalam menyerap tenaga kerja (SDM). Sedangkan rangking berikutnya dalam menyerap SDM adalah pada sub sektor Industri Kecil.

Aneka Industri sebagai sub sektor yang cukup strategis bagi pengembangan perindustrian kita di masa yang akandatang. Demikian juga pada sub sektor Industri Mesin Logam Dasar dan Elektronika tak kalah juga perannya bagi pengembangan SDM dan-perindustrian pada umumnya.

Oleh karena itu jika dibuat rangking bagi pengembangan SDM yang mampu mempercepat laju pertumbuhan ekonomi dan kemampuannya dalam melakukan proyeksi kemajuan Industri di masa depan akan terlihat seperti tertera dalam tabel berikut : 
Tabel 5

Proyeksi Ekspor sektor Industri

Perkelompok industri pada Repelita V s/d Repelita VI.

dalam US \$ milyar.

\begin{tabular}{|c|c|c|c|c|c|c|c|}
\hline \multirow{2}{*}{ Kelompok Industri- } & \multicolumn{3}{|c|}{ REPELITA V } & \multicolumn{4}{|c|}{ REPELITA VI } \\
\hline & $91 / 92$ & $92 / 93$ & $93 / 94$ & 94/95 & $95 / 96$ & $96 / 97$ & $97 / 98$ \\
\hline Aneka Industri & 11,30 & 13,13 & 15,46 & 18,24 & 21,52 & 25,39 & 29,97 \\
\hline IMLDE & 1,18 & 1,69 & 2,01 & 2,38 & 2,92 & 3,39 & 3,89 \\
\hline Industri Kecil & 1,74 & 1,97 & 2,27 & 2,61 & 3,03 & 3,48 & 4,01 \\
\hline I K D & 1,17 & $1,40^{*}$ & 1,65 & 1,95 & 2,30 & 2,72 & 3,21 \\
\hline
\end{tabular}

Sumber : Business News no. 5376/26-2-1993

Apalagi kalau kita lihat kecenderungan proyeksi perkembangan ekspor sektor industri sampai dengan akhir Repelita VI nahti, di mana Aneka Industri akan diharapkan akan meningkat pesat dalam kondisi yang mendominaasi. Kemudian menyusul Industri Logam Dasar. Maka penyiapan sumber daya manusia dalam menyongsong harapan tersebut mesti kita konsentrasikan pada sektor-sektor ini. Karena pada sektor-sektor inilah banyak dituntut untuk bisa berkompetisi dalam pasarglobal. Hal ini harus didukung dengan peningkatan kualitas sumber daya manusia yang bekerja pada sektor ini. Jika tidak diikuti denganpengembangan SDM, maka kita pasti tidak akan mampu bersaing di pasar global yang memang sarat dengan hasil produksi yang bermutu tinggi.

\section{Langkah-langkah Pengembangan.}

Dari pemaparan pentingnya pengembangan kualitas sumber daya manusia tersebut dengan segala harapan dan proyeksi sektor-sektor ekonomi yang perlu dikaitkan dengan usaha ini, maka berikut dapat dijadikan pertimbangan dalam menyusunlangkah-langkah pengembangan kualitas SDM sebagai berikut.

1. Kita harus menentukan sektor-sektor ekonomi yang potensial untuk mendukung bagi pengembangan ekonomi nasional.

2. Dari penentuantersebut kemudian kita fokuskan pada penyediaan dana yang cukup untuk pendidikan dan pelatihan sumberdaya manusiayangmendukung langkah 1 tersebut.

3. Memberikan seluas-luasnya kepada para atau calon entepreneurprofesional muda untuk mengembangkan usahanya tanpa pembedaan yang bersifat politis.

4. Mengembangkann dan merangsang lembaga manajemen dan lembaga pendidikan yang berorientasi pada kesiapan kerja pada jenjang menengah kebawah.

5. Merangsang dan mengembangkan lembaga manajemen yang berorientasi 
padaprofesi manajerial, yang sekaligus dapat merangsang kreatifitas bangsa dalam mencari bentuk dan warna yang khas sesuai dengan kepribadian bangsa.

6. Pemerintah dan masyarakathendaknya lebih menyediakan sarana latihạn dan ajangmelakukan pengalaman bagi para manajer muda atau calon manajer dalam kegiatan bisnis praktis dalam menyelenggarakan pendidikan manajemen.

7. Dalam menyelenggarakan pendidikan baik formal maupun non formal, terutama atas pendidikan politeknis atau kejuruan, perlu lebih diorientasikankembalipadakebutuhan pasar kerja.
8. Setiap departemen atau instansi ekonomi dan bisnis perlu menyediakan suatu sub sistem yang khusus menyelenggarakan pendidikan dan latihan untuk meningkatkan ketrampilan dan keahlian.

\section{Daftar Pustaka}

Biro Pusat Statistik Jakarta, tahun 1992.

Business. News no. 537 / 26-2-1993

Payaman Simanjuntak, EkonomiSumber Daya Manusia.

Majalah UNISIA no. 15 tahun XIII Triwulan IV - 1992

Nota Keuangan APBN 1992 / 1993

Warta Ekonomi no. 39/IV/22-Februari 1993 